\title{
High-rise buildings in the structure of an urbanized landscape and their influence on the spatial composition and image of the city
}

\author{
Valery K. Moor ${ }^{1,}{ }^{*}$, Elena A. Erysheva ${ }^{1}$ \\ ${ }^{1}$ Far Eastern Federal University, 690950, Vladivostok, Russia
}

\begin{abstract}
High-rise buildings play an important role in the spatial structure, composition and image of the city, as they are its spatial dominants and landmarks. The conditions of high-rise buildings perception in an urbanized landscape are changing in depending on the landscapemorphological conditions (the relief, the existence of the water area and the character of the coastline). Regularities of high-rise buildings' spatial organization in various natural-landscape situations are considered in the research; the basic principles of high-rise elements inclusion in structure of the urbanized landscape providing their harmonious interaction are formulated.
\end{abstract}

\section{Introduction}

High-rise buildings have significant role in the spatial structure, composition and image of the city because of their expression in the surrounding buildings. They represent spatial landmarks and often are original symbols of the urbanized landscape in the process of perception and comprehension of the city. In case if the natural landscape does not have a clearly defined structure, it does not affect the high-rise structure of the city, which is formed on the basis of other considerations (functional, constructive, economic, etc.). However, if the original natural landscape has a well-defined geomorphologic structure, it inevitably affects the morphology of the building, and the problem of their mutual coordination arises. In this case the natural landscape has a certain effect on the structure and image of the city, sets some "rules of behavior" that must be taken into account by the urban architect if he strives for harmony of the natural landscape and buildings. The aim of the research is to formulate the principles of including high-altitude elements in the structure of an urbanized landscape with a clearly defined relief, ensuring their harmonious interaction.

The problem of the relationship between the natural landscape and buildings is considered in a series of works [1-4]. Basic concepts are formulated and ways of urban development of the natural landscape are considered in these works. The influence of the natural landscape on the structure and image of the city, including its vertical composition is considered in other works [5-8]. Recently high-rise construction is increasingly being

\footnotetext{
*Corresponding author: moorv@rambler.ru
} 
considered in the context of sustainable development of the city's cultural landscape. In particular this problem is reflected in the works of a number of Russian and foreign authors [9-13]. The ongoing researches provide a rather wide field of modern ideas about the strategy, methodology and principles of sustainable development of the modern city's urban landscape. Despite the large amount of works in this direction, the problems of the relationship between high-rise construction and a sustainable, harmonious development have not been adequately studied. Base on this, it seems important to systematize this problems and formulate the basic principles of including high-rise elements in the structure of the urbanized landscape, ensuring their harmonious interaction, and hence, sustainable development.

\section{Methods}

The structural-morphological and architectural-composite analysis of urbanized landscapes of cities located in the water area and the clearly defined relief are used as the main research methods. The methods of urban planning analysis of the urbanized landscape were considered in the works of a number of authors [14-16]. The analysis and generalizing of these works, as well as carried out theoretical studies and experimental work, allowed to formulate the author's methods of analysis of the urbanized landscape, to reveal the basic principles of high-rise elements including in the structure of the urbanized landscape with clearly defined relief, ensuring their harmonious interaction $[17,18]$.

Let's consider in more detail the relationship of the natural landscape and buildings, primarily its vertically expressed elements (buildings and structures). High-rise buildings can play a different role in the spatial structure and architectural image of the city depending on the initial natural landscape situation. The main natural factors determining the role of high-rise buildings in the spatial composition of the city are as follows:

- the nature of the geomorphologic structure of the natural landscape;

- the existence of the water area and the nature of the coastline.

As for the nature of the geomorphologic structure of the natural landscape, it is largely determined by the relief. There are a large number of natural landscapes classifications. However it is sufficient to distinguish three different relief situations for purposes of subsequent analysis:

- the city is located on a flat or slightly defined relief;

- the city is located on medium and strongly defined, but undivided relief;

- the city is located on medium and strongly defined relief, which has a large degree of horizontal and vertical dissection (hilly relief).

These factors determine the conditions for the perception of high-rise buildings in the structure of the urban landscape in addition to directly influencing the shape and location of buildings. In some cases they make possible only a near and angular perception of high-rise buildings; in other cases they make conditions for the long-term perception of high-rise buildings in the structure of panoramic views or urban facades. Consider these three relief situations, from the point of view of the role and importance of high-rise buildings in the composition structure of the urbanized landscape, as well as the impact on the formation of the architectural and artistic image of the city.

The coastline is the most important composite element for the first relief situation. The nature of its irregularity determines the spatial structure and composition of the city, especially the part of the building that directly is located near the sea. The sea panorama of the city in this case is one-tier, the silhouette of the city is determined by the silhouette of the building. The influence of the coastline is particularly strong in cities located on the banks of deep-seated coves and bays, as well as in their location on peninsulas and islands. 
As the distance from the sea is increasing, the influence of the coastline on the structure and composition of the city is weakening (figure 1).

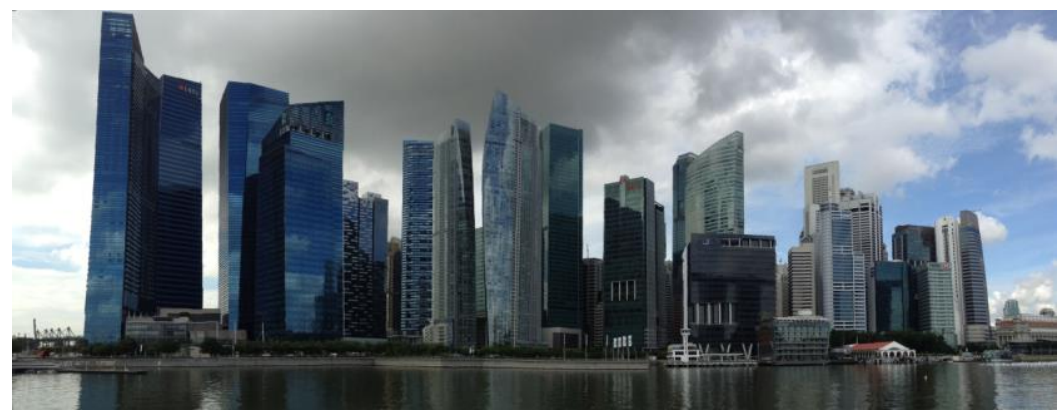

Fig. 1. High-rise buildings in conditions of unexpressed relief by the example of Singapore (photo by V.K. Moor).

The character of the water area, the outline of the coastline in this relief situation determine the shape, size and location of high altitude dominants in relation to the shore: they are usually located at key points, on the characteristic protrusions or bends of the shore, which allows them to occupy the most expressive positions in the spatial composition of the panorama. For example, in Venice, due to the lagoon's peculiarity, the dominant accents of the city - the tower of San Marco, the churches of San Giorgio Maggiore and Santa Maria Della Salute form a spatial triangle, the unchanging "frame" of the panorama as the points of perception of the city change.

Actively defined relief (the second relief situation) is an essential architectural component of the volumetric-spatial structure of the city. Along with the coastline it serves as the most important compositional precondition for the formation of the specificity of the spatial structure and artistic image of the seaside city. The spatial structure of a complex, active relief can be expressed by a system of axes, boundaries, centers, etc. They create a kind of "force fields" that penetrate the territory and determine the composition and spatial structure of the city. In turn, the nature of the coastline has a similar effect on the spatial organization of the city. In the context of complex relief, the value of the coastal strip increases. It captures not only the front of the building closest to the water area, but spreads through a visual interrelation much further (figure 2).

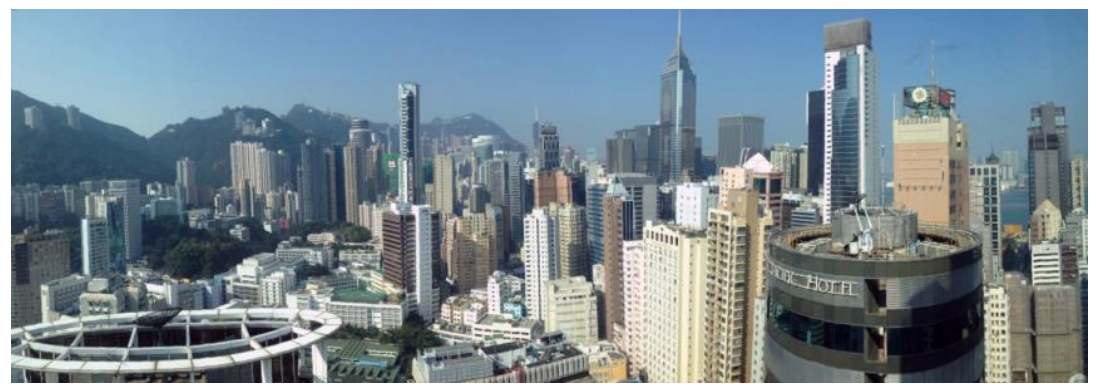

Fig. 2. High-rise buildings in a complex terrain based on the example of Hong Kong (photo by V.K. Moor).

Clearly defined relief creates conditions for a wide survey of urban formations, both from the sea side and (in case of a sloping and rugged coastline) from within the urban space. In this situation the city is perceived multilevel, and its silhouette is determined by imposing a silhouette of the building on the silhouette of the natural landscape. Architectural dominants play the role of landmarks of a considerably larger range of action 
than in plain conditions. They often represent a coherent system of spatial orientation of the city.

The panorama of such city is multilevel and multifaceted and quite dynamic when perceived in movement. The coastline forms a clearly defined border of the city, forming the first plan of the panorama, predetermines the direction of development of the urban composition. We can identify certain spatial "layers" of the city, differing in the level of communication with the sea (direct communication, visual communication), which play a different role in the panorama's formation. Especially acute and emotional it happens when approaching the city from the sea, when the foreground, "floating into the frame," constantly changes panoramic pictures.

The third relief situation - an actively expressed and complexly dissected relief - largely retains the space-organizing qualities described above. At the same time, a number of new qualities and compositional features appear here. A complexly dissected relief, such as a hilly terrain with significant elevations, is characterized by the polycentricity of the "force field", the complex imposition of composite form-building forces. In addition, in this situation, we are faced with slopes of different orientations to the sides of the world, as well as in relation to the sea. In each such case, there are regularities and methods for the formation of urban development. Complexly dissected relief is characterized by a large number of visual perspectives and interrelations between the structural elements of the city. The variety of species, sometimes unexpected, makes the perception dynamic and emotionally saturated (figure 3).

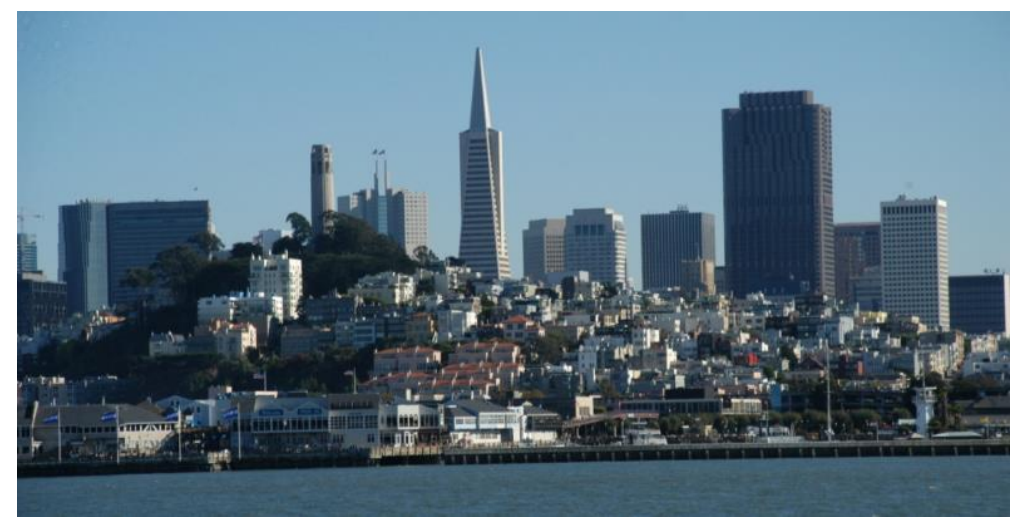

Fig. 3. High-rise buildings in difficultly dissected hilly terrain on the example of San Francisco, USA (photo by Vishnu Vardhan)

Of course, the formation of the city planning structure takes place under the influence of a number of factors, and in reality there are situations when the possibility and necessity of a visual relationship with the sea is "crossed out" by other circumstances (for example, the orientation of the slope in the sides of the world, the unfavorable effects of prevailing winds, Etc.). However, practice shows that the visual relationship with the sea is one of the most important conditions for the formation of the seaside city, its artistic image. Therefore, there are resourses, methods and forms of resolving this contradiction in the direction of preserving such a relationship even in the presence of unfavorable factors.

The examples considered above characterize the simplest forms of the relationship between the natural landscape and the planning structure of the seaside city. In reality, more complex situations arise, as, for example, in the Far Eastern seaside cities, Vladivostok is a representative of which. First, here the natural landscape is a difficult dissected, hilly terrain; different parts of this territory have different slopes, different orientations in the sides of the world and differently correlate with the sea. Secondly, the natural landscape is 
characterized by a complex coastline, deep bays and protruding peninsulas, as well as the island part. Consequently, the spatial and visual connections of the city and the sea are more complex here (figure 4). It is necessary to keep certain principles in order to ensure harmony of the natural landscape and high-rise buildings. Those principles are formulated below according to the results of the research.

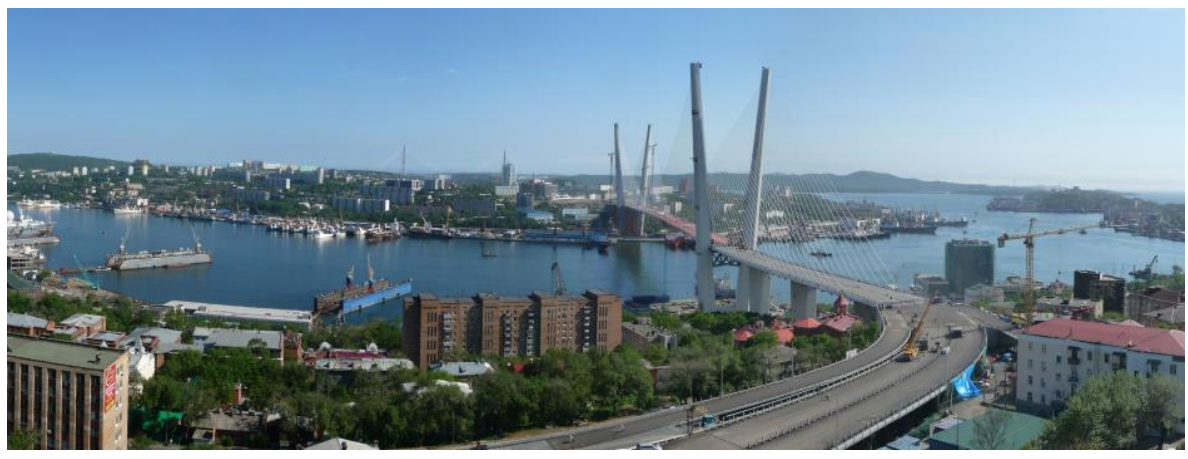

Fig. 4. The urban landscape of Vladivostok (photo by V.K. Moor).

As the analysis shows, the natural landscape of Vladivostok has a complicated polycentric character. In this regard, the planning structure of the buildings and its vertical composition should be coordinated with the natural landscape in order to be in harmony with it. High-rise buildings will form complex harmonious compositions organizing and identifying numerous hills and creating the basis for the sustainable development of the cultural landscape.

\section{Results}

Researches and experimental projects were conducted at the Department of Architecture and Urban Design of the Far Eastern Federal University (FEFU) for a long time, the purpose of which was the development of methodology, strategy and principles for improving and humanizing the existing environment of the Far Eastern seaside cities. The researches and experimental projects allowed formulating some general principles of renovation of the urban environment, including those relating to high-rise buildings [1921].

The basic principles of including high-rise elements in the structure of an urbanized landscape with a clearly defined relief, ensuring their harmonious interaction, can be characterized as follows:

1. Principle of structural coordination of the natural landscape morphology and vertical buildings elements (high-rise buildings and structures). In accordance with this principle, high-rise buildings, due to their compositional significance, should be located on characteristic areas of the terrain, emphasizing and revealing the structure of the landscape. In reality, this requirement is often not observed, hence one of the reasons for the disharmony of buildings and landscape.

2. The principle of modular coordination of the natural landscape morphology and the geometric shape of high-rise building elements. The lack of modular coordination of the landscape and high-rise buildings leads to their disharmony, and we also often observe this shortcoming in practice.

3. The principle of differentiation of town-planning methods of construction and the plastic structure of high-rise buildings, depending on the development of certain tiers of the natural landscape. This means that in order to preserve the aesthetically valuable elements 
of the natural landscape, it is necessary to apply building methods specific for each tier of the relief, including high-rise buildings.

4. The principle of grouping high-rise elements into an integral composite system that provides artistic unity and expressiveness of the high-rise structure and silhouette of the urbanized landscape. As practice shows, solitary high-rise buildings often do not create expressed rhythmic structures in space and, thus, do not form an artistically expressive composition. It is no accident therefore high-rise buildings are very often grouped into clusters.

5. The principle of active semantic interpretation of high-rise elements as the most significant elements of the urbanized landscape. High-rise buildings must concentrate in themselves figuratively-symbolic content, be original "tower-symbols of the place" to become dominant and spatial reference points in the cultural landscape of the city.

\section{Discussions}

The above principles of including high-rise elements in the structure of the urbanized landscape have been tested in a series of experimental architectural and town-planning projects carried out at the Department of Architecture and Urban Planning of the FEFU in the framework of the graduation project. Project proposals have been elaborated for the development and improvement of the spatial structure and architectural image of Vladivostok In these works. One of the main tasks in these projects was the improvement of the high-rise structure and silhouette of the city on the basis of the principles formulated above, ensuring a harmonious interaction of high-rise buildings and natural context.

The problem is that the natural landscape of Vladivostok has a complex polycentric character. In this regard, the planning structure of the buildings and its vertical composition should be coordinated with the natural landscape in order to be in harmony with it on the base of certain principles and methodology. The hypothesis was that the formulated principles would solve this design problem. And, thus, the applying of these principles will improve the high-rise composition of the city, creating a basis for the sustainable development of the cultural landscape.

Let us consider several examples of these projects. A new proposal for the formation of spatial structure of the southern coast of the Golden Horn Bay in Vladivostok, which has been intensively developing recently, offered in the project by O.V. Zvereva. To this end, the author conducts a complex analysis of the natural landscape, reveals its compositional structure, planning and volume module, the main compositional axes and characteristic points of perception. The functional-planning structure of this part of Vladivostok was also analyzed. A detailed study of the initial environment is a prerequisite for the sustainable development of the cultural landscape. Based on this analysis, a more effective solution to the spatial structure and architectural image of the Golden Horn Bay's southern slope is proposed. The project also developed a specific architectural and spatial solution of one of the city modules, including a principal solution to its vertical structure (figure 5a).

A new public and business center on Russkiy Island in Vladivostok was developed in the project by S.F. Valeev. The territory of the social and business center has a unique natural landscape; this place plays an active role in the formation of the maritime facade of Vladivostok. The project was preceded by a multifactor analysis of the natural landscape, as well as a comparative analysis of analogues. The proposed planning solution emphasizes the natural peculiarity of the site; it fits organically into the natural landscape. At the heart of the spatial solution is the idea of a developed town-planning structure, solved in the form of several terraces placed on the natural tiers of the landscape. The structure of the townplanning complex includes three spatial dominants, each of which is a group of high-rise buildings, original "crystals" of development. The complex consists of the following 
functional zones: business, residential, entertainment, park, cultural. Detailed pre-project analysis, rather organic interaction with the natural landscape, an interesting interpretation of the spatial composition, silhouette and panorama of the public-business complex are the advantages of the project (figure $5 b$ ).
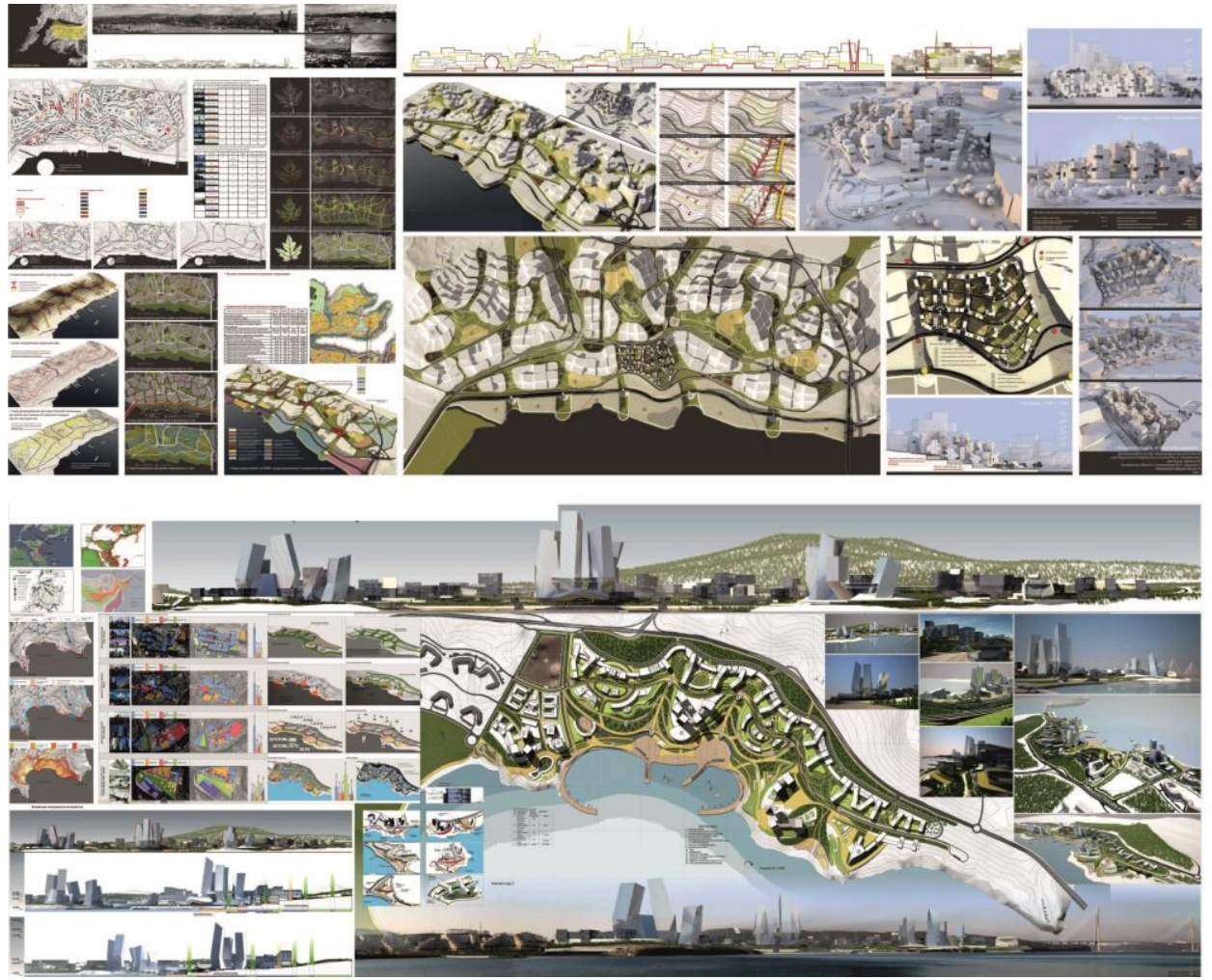

Fig. 5. Examples of Graduation architectural projects:

a - "Formation of the spatial composition of Golden Horn Bay's southern coast, Vladivostok" (Author O.V. Zvereva, tutors Professor V.K. Moor, Professor V.I. Smotrikovskiy, Associate Professor A.G. Gavrilov); b - "New public and business center on Russkiy Island in Vladivostok (Author S.F. Valeev, tutors Professor V.K. Moor, Associate Professor A.G. Gavrilov)

In addition to the above works on the FEFU Department of Architecture and Urban Design, a large number of similar architectural projects were carried out, in which the problem of high-rise buildings in a complex relief was solved. The approbation showed that taking into account the basic principles of including high-rise elements in the structure of the urbanized landscape in a series of experimental projects allowed ensuring a harmonious interaction of high-rise buildings and the natural context. The projects were highly appreciated at the state attestation; they were repeatedly exhibited at different architectural competitions and were awarded professional awards and prizes.

\section{Conclusions}

High-rise buildings play an important role in the spatial structure and image of the city, as they are significant elements of the cultural landscape. Sustainable development of the city's cultural landscape implies adherence to certain principles for including high-rise buildings in urban context. These principles depend on the structure of the natural landscape (the relief, the existence of water and the character of the shoreline), as they 
determine the conditions for the perception of high-rise buildings in an urbanized landscape. Analysis of regularities in the spatial organization of high-rise buildings in three different natural landscape situations has revealed specific techniques and principles for including high-rise elements in the structure of the urbanized landscape that ensure their harmonious interaction. The basic principles of including high-rise elements in the structure of an urbanized landscape with an actively expressed hilly terrain: structural and modular coordination of the morphology of the natural landscape and high-rise buildings; tier differentiation of town planning techniques for high-rise buildings; grouping of high-rise elements in an integrated composite system; active semantic interpretation of high-rise elements as the most significant elements of an urbanized landscape.

\section{References}

1. T. G. Maklakova, Visotnyie zdaniya. Gradostroitelnyie i arhitekturno-konstruktivnyie problemyi proektirovaniya (Moskva, ASV, 2008)

2. Yu. V. Razumovskiy, L. M. Fursova, V. S. Teodoronskiy, Landshaftnoe proektirovanie, (Moskva, Forum, 2016)

3. S.I. Palienko, Arhitekturnyie zadachi vertikalnoy planirovki territoriy so slozhnyim relefom, (Vladivostok, DVGTU, 2007)

4. A. V. Gorodkov, Arhitektura, proektirovanie i organizatsiya kulturnyih landshaftov (Sankt-Peterburg, Prospekt Nauki, 2013)

5. V.P. Generalov, Osobennosti proektirovaniya vyisotnyih zdaniy (Samara, SamGASU, 2009)

6. Proektirovanie sovremennyih vyisotnyih zdaniy, Pod red. Syuy Peyfu (Moskva, ASV,2008)

7. A. A. Magay, Arhitekturnoe proektirovanie vyisotnyih zdaniy i kompleksov (Moskva, ASV, 2015)

8. Osobennosti proektirovaniya i vozvedeniya, Vyisotnyie zdaniya i drugie unikalnyie sooruzheniya Kitaya (Moskva, ASV, 2013)

9. Y. Jabareen, Sustainable urban forms: Their typologies, models, and concepts, 26, 3852 (J. Plan. Educ. Res. 2006)

10. O. A. Lavrenova, Prostranstva i smyislyi: Semantika kulturnogo landshafta (Moskva, Institut Naslediya, 2010)

11. UNESCO. Recommendation on the Historic Urban Landscape (UNESCO World Heritage Centre, Paris, France, 2011)

12. T. A. Smolitskaya, T. O. Korol, E. I. Golubeva, Gorodskoy kulturnyiy landshaft: traditsii i sovremennyie tendentsii razvitiya (Moskva, Liberkom, 2014)

13. V. K. Moor, E. A. Erysheva, Ustoychivoe razvitie kulturnogo landshafta goroda. Ustoychivaya arhitektura: nastoyaschee i buduschee, Proc. of Int. Sci. Conf., 17-18 noyabrya 2011 (Moskva, OOO «Adelant», 2012)

14. Lorraine Farrelly, Drawing for Urban Design (London, Laurence King Publishing, 2011)

15. V. A. Sosnovskiy, N. S. Rusakova, Prikladnyie metodyi gradostroitelnyih issledovaniy (Moskva, «Arhitektura S», 2006)

16. M. V. Shubenkov, Strukturnyie zakonomernosti arhitekturnogo formoobrazovaniya (Moskva, «Arhitektura S», 2006) 
17. V. K. Moor, A. G. Gavrilov, E. A. Erysheva, Arhitekturnaya masterskaya V. Moora: shkola, laboratoriya, studiya (Vladivostok, DVFU, 2013)

18. A. G. Babenko, A. G. Gavrilov, E. A. Erysheva, G. E. Ignatov, A. V. Kopeva, O. V. Maslovskaya, V. K. Moor, S. I. Palienko, Rekonstruktsiya slozhivsheysya zhiloy sredyi primorskogo goroda (Vladivostok, DVGTU, 2004)

19. V. K. Moor, A. G. Gavrilov, A. V. Kopeva, Formirovanie vladivostokskoy arhitekturnoy shkolyi, Spetsialnost «Arhitektura» v DVGTU (Vladivostok, DVGTU, 2009)

20. V. K. Moor, A. G. Gavrilov, Katalog luchshih diplomnyih proektov, Spetsialnost «Arhitektura», DVPI-DVGTU, 1980-2009 (Vladivostok, DVGTU, 2010)

21. E. A. Erysheva, V. K. Moor, T. A. Demidova, The best Projects of Far Eastern Architectural School (Russia, Vladivostok. Harbin, Hitpress, 2007) 